\title{
Genetic Identification of Spotted Owls, Barred Owls, and Their Hybrids: Legal Implications of Hybrid Identity
}

\author{
SUSAN M. HAIG,${ }^{*}$ THOMAS D. MULLINS,${ }^{*}$ ERIC D. FORSMAN, $†$ PEPPER W. TRAIL, $\neq$ \\ AND LIV WENNERBERG*†† \\ ${ }^{*}$ U.S. Geological Survey, Forest and Rangeland Ecosystem Science Center, 3200 SW Jefferson Way, Corvallis, OR 97331, U.S.A. \\ †U.S. Department of Agriculture Forest Service, Pacific Northwest Forest Experiment Station, 3200 SW Jefferson Way, \\ Corvallis, OR 97331, U.S.A. \\ ‡U.S. Fish and Wildlife Service, National Fish and Wildlife Forensics Laboratory, 1490 E. Main Street, Ashland, OR 97520, U.S.A.
}

\begin{abstract}
Recent population expansion of Barred Owls (Strix varia) into western North America bas led to concern that they may compete with and further harm the Northern Spotted Owl (S. occidentalis caurina), which is already listed as threatened under the U.S. Endangered Species Act (ESA). Because they bybridize, there is a legal need under the ESA for forensic identification of both species and their bybrids. We used mitochondrial control-region DNA and amplified fragment-length polymorphism (AFLP) analyses to assess maternal and biparental gene flow in this bybridization process. Mitochondrial DNA sequences (524 base pairs) indicated large divergence between Barred and Spotted Owls (13.9\%). Further, the species formed two distinct clades with no signs of previous introgression. Fourteen diagnostic AFLP bands also indicated extensive divergence between the species, including markers differentiating them. Principal coordinate analyses and assignment tests clearly supported this differentiation. We found that bybrids bad unique genetic combinations, including AFLP markers from both parental species, and identified known bybrids as well as potential bybrids with unclear taxonomic status. Our analyses corroborated the findings of extensive field studies that most bybrids genetically sampled resulted from crosses between female Barred Owls and male Spotted Owls. These genetic markers make it possible to clearly identify these species as well as bybrids and can now be used for research, conservation, and law enforcement. Several legal avenues may facilitate future conservation of Spotted Owls and other ESA-listed species that bybridize, including the ESA similarity-of-appearance clause (section 4[e]) and the Migratory Bird Treaty Act. The Migratory Bird Treaty Act appears to be the most useful route at this time.
\end{abstract}

Key Words: AFLP, conservation genetics, Endangered Species Act, hybridization, Migratory Bird Treaty Act, mtDNA

Identificación Genética de Strix occidentalis caurina y $S$. varia y sus Híbridos: Implicaciones Legales de la Identidad Híbrida

Resumen: La reciente expansión de la población de Strix varia hacia el oeste de Norte América ba llevado a la preocupación de que puede competir con y posteriormente dañar a S. occidentalis caurina, que está enlistada como amenazada en el Acta de Especies en Peligro de E. U. (AEP). Debido a que bibridan, por mandato de AEP hay una necesidad legal de la identificación forense de ambas especies y sus híbridos. Utilizamos análisis de ADN de la región de control mitocondrial y polimorfismo de longitud de fragmento amplificado (PLFA) para evaluar el flujo génico materno y biparental de este proceso de bibridación. Las secuencias de ADN mitocondrial (524 pares de bases) indicaron una amplia divergencia ente Strix varia y S. occidentalis caurina (13.9\%). Más

§email susan_haig@usgs.gov

††Current address: University of Oslo, P. O. Box 1172 Blindern, 0318 Oslo, Norway.

Paper submitted May 8, 2003; revised manuscript accepted June 1, 2004.

This article is a U.S. government work, and is not subject to copyright in the United States. 
aun, las especies formaron dos clados diferentes sin signos de introgresión previa. Catorce bandas diagnóstico de PLFA también indicaron divergencia extensiva entre especies, incluyendo marcadores que diferencian a las especies. Análisis de componentes principales y pruebas de acomodo claramente sustentaron a esta diferenciación. Encontramos que los híbridos tenían combinaciones genéticas únicas, incluyendo marcadores PLFA de ambas especies parentales e identificaban a bíbridos conocidos así como a los potenciales híbridos con estatus taxonómico incierto. Nuestros análisis corroboraron extensivos estudios de campo que la mayoría de los híbridos muestreados genéticamente resultaron de cruzas entre bembras de Strix varia y machos de $\mathrm{S}$. occidentalis caurina. Estos marcadores genéticos hacen que sea posible identificar claramente a estas especies así como a sus híbridos y abora pueden ser utilizados para investigación, conservación y aplicación de la ley. Varias rutas legales pueden facilitar la conservación futura de S. occidentalis caurina y otras especies enlistadas en AEP que bibridan, incluyendo la cláusula de similitud de apariencia de AEP (sección 4[e]) y el Acta del Tratado de Aves Migratorias. Por el momento, el Acta del Tratado de Aves Migratorias parece ser la ruta más útil.

Palabras Clave: Acta de Especies en Peligro, Acta del Tratado de Aves Migratorias, ADNmt, genética de conservación, hibridación, PLFA

\section{Introduction}

Hybridization between species can severely affect a species' status and recovery ( Rhymer \& Simberloff 1996). Threatened species (and others) may be directly affected by hybridization and gene flow from invasive species, which can result in reduced fitness or lowered genetic variability (Bert et al. 1993, Gottelli et al. 1994, Wolf et al. 2001). In other cases, hybridization may provide increased polymorphisms that allow for rapid evolution to occur (Grant \& Grant 1992; Rhymer et al. 1994). Species can also be influenced indirectly, because hybridization may affect the conservation status of threatened species and their legal protection (O'Brien \& Mayr 1991a, 1991b; Jones et al. 1995; Allendorf et al. 2001; Schwartz et al. 2004; Haig \& Allendorf 2005).

The Northern Spotted Owl (Strix occidentalis caurina) is a threatened subspecies associated with rapidly declining, late-successional forests in western North America (Gutiérrez et al. 1995). Listing of this subspecies under the U.S. Endangered Species Act (ESA) attracted considerable controversy because of concern that listing would lead to restrictions on timber harvest. A close relative, the Barred Owl (S. varia), occurred historically from south-central Mexico through the eastern United States and eastern Canada south of the boreal forest (Mazur \& James 2000). Since the early 1900s, Barred Owls have rapidly expanded their range westward across central Canada and southward into Idaho, Montana, Washington, Oregon, and northern California (Fig. 1; Grant 1966; Taylor \& Forsman 1976; Wright 1977; Dunbar et al. 1991; Wright \& Hayward 1998; Houston \& McGowan 1999; Holt et al. 2001; Kelly et al. 2003). They first appeared in Washington in 1965 (Reichard 1974), in Oregon in 1974 (Taylor \& Forsman 1976), and in California in 1981 (Dark et al. 1998). In Oregon over 700 territories have been found since 1974, and an average of 60 new territories were found per year between 1989 and 1998 (Kelly et al. 2003). Numerous hypotheses have been proposed to explain this radiation, ranging from forest expansion due to climate change in central Canada to forest management practices in the Pacific Northwest, but none have been definitively proven (Kelly et al. 2003; Peterson \& Robins 2003). Thus, ranges of the two species now overlap to a large extent (Fig. 1), and competition between the species is a threat to Spotted Owl persistence (Forsman et al. 1996; Kelly et al. 2003).

The current extent of hybridization is unknown, although over 50 hybrids have been identified (Hamer et al. 1994; Dark et al. 1998; Kelly 2001; this study). The fitness consequences of this hybridization have not been studied but need to be considered as a potential threat to Spotted Owls. Further, observations indicate that at least some hybrids are fertile and successfully raise offspring to fledging (Hamer et al. 1994; Kelly 2001; this study).

The legal status of hybrids under the ESA is ambiguous at best; hence, hybridization between Barred and Spotted owls complicates management of Northern Spotted Owls in direct and indirect ways (O'Brien \& Mayr 1991a, $1991 b$; U.S. Fish and Wildlife Service [USFWS] 1996; Allendorf et al. 2001). However, the ability to identify hybrids is the first step in evaluating the extent of hybridization and prioritizing conservation activities, including law enforcement, for Spotted Owls. Visual and vocal identification of hybrids can be difficult; thus, we developed two types of molecular genetic markers for hybrid identification: mitochondrial DNA (mtDNA) sequences and amplified fragment-length polymorphisms (AFLP). Mitochondrial DNA, which is frequently used in studies of hybridization (e.g., Gill 1997; Rohwer et al. 2001; Saetre et al. 2001), reflects maternal gene flow. The DNA from both parental species is detected with AFLPs (e.g., Liu et al. 2000; Bensch et al. 2002; Mock et al. 2002).

Our approach to identification of hybrids between Barred and Spotted owls was threefold: (1) genetic differentiation between the two parental species was described based on mitochondrial DNA sequencing and AFLP 


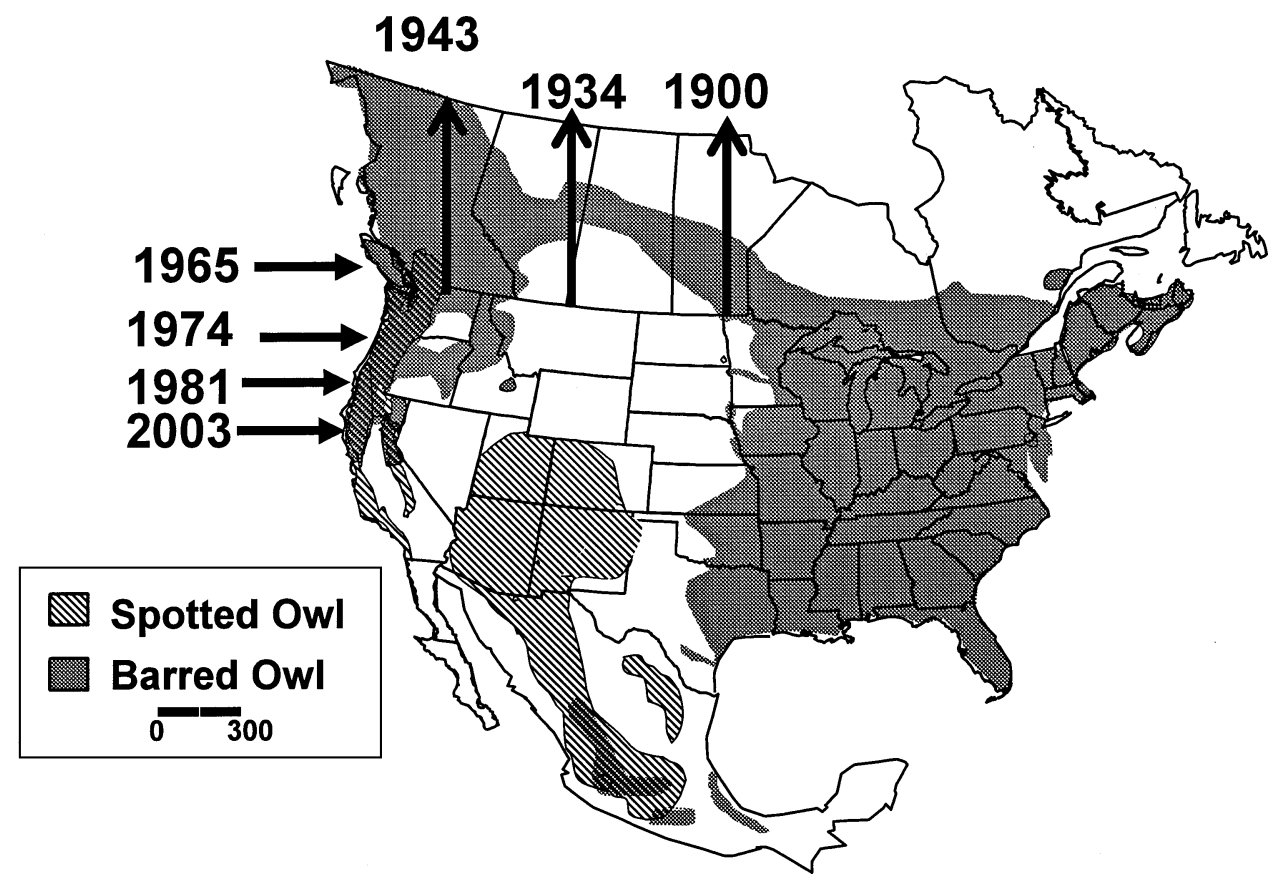

Figure 1. Current breeding range of Spotted Owls, current and historic breeding range of Barred Owls (indicated by arrows and years), and areas of overlap between the two species (see text for references). Sampling localities for hybrid owls and potential bybrids are indicated in Table 2.

analyses, and genetic markers identifying hybrids were developed; (2) these markers were used to ascertain the parental derivation of individuals identified as hybrids in the field; (3) markers were tested on individuals whose hybrid status was unclear. Once the markers were identified, we considered the legal options for protecting ESAlisted species in a situation similar to the Spotted Owl hybrids.

\section{Methods}

\section{Samples}

Samples of Spotted Owls, Barred Owls, and SpottedBarred Owl hybrids were collected mainly in the northwestern United States, where hybridization occurs (Tables $1 \&$ \& ; Fig. 1). Initial taxonomic identification of Spotted Owls and hybrids was based on plumage attributes and vocalizations documented by field biologists during long-term monitoring of Spotted Owl populations (E.D.F., unpublished data). We collected Barred Owl tissue from specimens at the USFWS Fish and Wildlife Forensic Laboratory (Ashland, Oregon), the U.S. Geological Survey's Wildlife Health Laboratory (Madison, Wisconsin), the Portland Zoo (Oregon), and several raptor rehabilitation facilities.

Presumed hybrids (1-7) were identified in the field based on plumage characteristics, vocalizations, and morphological measurements as described by Hamer et al. (1994) or by species identification of both parents (Table 2). In addition, we examined tissue samples from three potential hybrids (8-10) for which taxonomic status was unresolved by field biologists.
Samples consisted of blood or feathers from trapped individuals and tissue from the muscle or toe pads of museum specimens. Blood and tissue were placed in buffer (100 mM Tris, $100 \mathrm{mM}$ EDTA, $10 \mathrm{mM} \mathrm{NaCl}, 0.5 \%$ SDS) and stored at $-80^{\circ} \mathrm{C}$. The DNA was extracted by phenol/chloroform extraction (Sambrock et al. 1989; Smith et al. 1996), and concentrations were measured on a DyNA Quant 200 Fluorometer (Hoefer) with a calf thymus DNA standard DQ202 (Hoefer). We diluted samples to $50 \mathrm{ng} / \mu \mathrm{L}$.

Table 1. Geographic origin and sample sizes of Spotted Owls, ${ }^{a}$ Barred Owls, and hybrid owls used for mtDNA, ${ }^{b}$ and AFLPc analyses.

\begin{tabular}{|c|c|c|c|}
\hline Species & State & $m t D N A$ & AFLP \\
\hline \multirow[t]{9}{*}{ Barred Owl } & Washington & 6 & 5 \\
\hline & Oregon & 14 & 11 \\
\hline & Wisconsin & 9 & 7 \\
\hline & Maryland & 1 & 0 \\
\hline & Virginia & 1 & 0 \\
\hline & Florida & 1 & 0 \\
\hline & Oklahoma & 1 & 1 \\
\hline & Texas & 4 & 3 \\
\hline & unknown & 1 & 1 \\
\hline \multirow[t]{5}{*}{ Spotted Owl } & Washington $^{d}$ & 20 & 8 \\
\hline & Oregon $^{d}$ & 81 & 8 \\
\hline & California $^{d}$ & 30 & 4 \\
\hline & California $^{e}$ & 37 & 8 \\
\hline & Arizona $^{f}$ & 25 & 9 \\
\hline \multirow{2}{*}{$\begin{array}{l}\text { Hybrids or potential } \\
\text { hybrids }\end{array}$} & Washington & 2 & 2 \\
\hline & Oregon & 8 & 7 \\
\hline
\end{tabular}

${ }^{a}$ Spotted Owl mtDNA data from Haig et al. (2004).

${ }^{b}$ Mitochondrial DNA.

${ }^{c}$ Amplified fragment-length polymorphism.

${ }^{d}$ Northern Spotted Owl.

${ }^{e}$ California Spotted Owl.

${ }^{f}$ Mexican Spotted Owl. 
Table 2. Field information about Spotted Owl (SPOT) and Barred Owl (BARR) hybrids (1-7) and potential hybrids (8-10).

\begin{tabular}{|c|c|c|c|c|c|c|c|c|}
\hline Hybrid & $\operatorname{Sex}$ & $\begin{array}{c}\text { Basis for } \\
\text { bybrid status }\end{array}$ & State $^{a}$ & Location $^{a}$ & male & female & Mate & Offspring \\
\hline 2 & M & morphology & OR & $\begin{array}{l}\text { Lane Co., Eugene BLM, Meadow } \\
\text { Creek }\end{array}$ & SPOT? & BARR? & SPOT, BARR $^{b}$ & 1,3 \\
\hline 4 & M & pedigree & OR & $\begin{array}{l}\text { Douglas Co., Roseburg, Turkey } \\
\text { Creek }\end{array}$ & SPOT? & BARR? & - & - \\
\hline 5 & M & morphology & OR & $\begin{array}{l}\text { Jackson Co., Rogue River NF, } \\
\text { Lick Creek }\end{array}$ & unknown & unknown & SPOT, BARR $^{b}$ & 2,0 \\
\hline 6 & $\mathrm{~F}$ & morphology & WA & $\begin{array}{l}\text { Clallam Co., Bogachiel Valley, } \\
\text { Mosquito Flats }\end{array}$ & unknown & unknown & BARR & 0,0 \\
\hline
\end{tabular}

a Abbreviations: OR, Oregon; WA, Washington; Co, county; BLM, Bureau of Land Management; NF, national forest; DNR, Department of Natural Resources.

${ }^{b}$ Changed mates between years.

\section{Mitochondrial DNA Sequencing}

The DNA from a 524 bp portion of the mitochondrial control region (D-loop) was sequenced for Barred Owls, hybrids, and potential hybrids. Our analyses also included DNA sequences from the same region in Spotted Owls (Haig et al. 2004).

The control region was amplified by PCR on a PCT 100 thermal cycler (MJ Research, Waltham, Massachusetts), with the primers N1 and D16 (Barrowclough et al. 1999). We used the following parameters for amplification: 2minute denaturation at $94^{\circ} \mathrm{C} ; 35$ cycles of $94^{\circ} \mathrm{C}$ for 30 seconds, $50^{\circ} \mathrm{C}$ for 30 seconds, and $72^{\circ} \mathrm{C}$ for 1 minute; and a final elongation at $72^{\circ} \mathrm{C}$ for 10 minutes. The PCR product was cleaned and concentrated by centrifugation dialysis with Microcon 30,000 MW filters (Millipore, Billerica, Massachusetts). We used Internal primers D11 (Barrowclough et al. 1999) and BO24 (5'-TGATATAGGAACCAG AGGC-3') to generate bidirectional continuous DNA sequence of domain I through a portion of domain II in the control region. Sequencing was performed on an ABI Prism 3100 automatic DNA sequencer, with ABI Primers and the Big Dye Terminator Cycle Sequencing v2.0 Ready Reaction kit. Sequences were run at the Central Services Laboratory at Oregon State University.

We aligned sequences manually with BioEdit 5.0.1 (Hall 1999). Haplotype diversity (h) and nucleotide diversity $(\pi)$ were calculated with DnaSP (Rozas \& Rozas 1999). We analyzed genetic variation further in Arlequin 2.001 (Schneider et al. 2000), calculating haplotype frequencies, number of transitions, transversions, indels, and average pairwise sequence divergences within and between species. We used the program PAUP $4.0 \mathrm{~b} 10$ (Swofford
2002) to estimate phylogenetic relationships with maximum parsimony and maximum-likelihood criteria and the neighbor-joining approach. We generated trees using 100 replicate heuristic searches with random taxon addition (10 replicates). Reliability of support for tree nodes was assessed for each method by bootstrap consensus (100 replicates; Felsenstein 1985). Likelihood-ratio tests were implemented in the program Modeltest v3.06 (Posada \& Crandall 1998) to determine the optimum minimumparameter maximum-likelihood model. The hierarchical likelihood-ratio test and Akaike information criterion selected the Tamura-Nei (1993) model of substitution plus gamma $(\operatorname{TrN}+\mathrm{I}+\mathrm{G})$; gamma-shaped parameter 0.1916 with $\forall=0.1426$ was estimated from the data. Neighborjoining and maximum-likelihood trees were constructed in PAUP with the parameter estimates described above. All trees were unrooted.

\section{Amplified Fragment-Length Polymorphism Analyses}

We conducted amplified fragment-length polymorphism analyses according to Vos et al. (1995), with some modifications. In short, $0.5 \mu \mathrm{g}$ genomic DNA was incubated for 1 hour at $37^{\circ} \mathrm{C}$ with 5 units Eco RI and 10 units Mse I in $20-\mu \mathrm{L}$ reaction buffer 'REact3' (Invitrogen, Life Technologies, Carlsbad, California) and $50 \mathrm{ng} / \mu \mathrm{L}$ BSA. Thereafter, a cocktail was added to this mixture containing 2.5 PMol Eco RI adaptor (Vos et al. 1995), 25 PMol Mse I adaptor (Vos et al. 1995), $0.5 \mu \mathrm{L} 10 \times \mathrm{T} 4$ DNA ligation buffer (Promega), 0.5-unit T4 DNA-ligase (Promega), and $\mathrm{dH}_{2} \mathrm{O}$ to a total volume of $5 \mu \mathrm{L}$. We continued incubation for 3 hours at $37^{\circ} \mathrm{C}$. The reaction mixture was diluted tenfold in $\mathrm{dH}_{2} \mathrm{O}$. 
We performed preamplification PCR with Eco RI primer $\mathrm{E}_{\mathrm{T}}$ (5'-GACTGCGTACCAATTCT- $\left.3^{\prime}\right)$ and Mse I primer $M_{C}\left(5^{\prime}\right.$-GATGAGTCCTGAGTAAC-3'), with the following temperature profile: $94^{\circ} \mathrm{C}$ for 2 minutes; 20 cycles of $94^{\circ} \mathrm{C}$ for 30 seconds, $56^{\circ} \mathrm{C}$ for 30 seconds, and $72^{\circ} \mathrm{C}$ for 1 minute, and a final elongation at $72^{\circ} \mathrm{C}$ for 10 minutes. The preamplification PCR product was diluted 10 -fold and stored at $-20^{\circ} \mathrm{C}$. In the second selective amplification, the PCR included $94^{\circ} \mathrm{C}$ for 2 minutes, a 12-cycle touchdown procedure of $94^{\circ} \mathrm{C}$ for 30 seconds, $60-0.7^{\circ} \mathrm{C} / \mathrm{cycle}$ for 30 seconds, and $72^{\circ} \mathrm{C}$ for 1 minute; 23 cycles of $94^{\circ} \mathrm{C}$ for 30 seconds, $56^{\circ} \mathrm{C}$ for 30 seconds, $72^{\circ} \mathrm{C}$ for 1 minute, and elongation at $72^{\circ} \mathrm{C}$ for 10 minutes. Primers with three selective nucleotides were used in four combinations: $\mathrm{E}_{\mathrm{TAG}} * / \mathrm{M}_{\mathrm{CGA}}, \mathrm{E}_{\mathrm{TAG}} * / \mathrm{M}_{\mathrm{CTG}}, \mathrm{E}_{\mathrm{TCT}} * / \mathrm{M}_{\mathrm{CGA}}$, and $\mathrm{E}_{\mathrm{TCT}} * / \mathrm{M}_{\mathrm{CTG}}$. We labeled the Eco RI primers (E) with FAM at the $5^{\prime}$ end. The PCR products were run on 5\% polyacrylamide gels for 4 hours on an ABI 377 automated DNA sequencer (Applied Biosystems) with filter set A. We ran all samples with an internal lane standard (2500 Rox). Amplified fragment-length polymorphism data were analyzed with GeneScan 3.1.2 and Genotyper 2.5. The choice of specific markers (bands) was based on their utility for species and hybrid identification. Initially, we screened 10 individuals of each species for suitable markers. Markers with the most pronounced differences in frequency between the two species were selected and scored for all individuals. The DNA from the toe pads of museum specimens showed clear patterns of degraded DNA (few and short bands only) and were excluded from further AFLP analyses.

We scored amplified fragment-length polymorphisms for presence or absence of the selected bands. Results of all bands were also pooled into a principle coordinate analysis (PCO) with MultiVariate Statistical Package 3.0 (1998, Kovach Computing Services, Anglesey, Wales; http://www.kovcomp.co.uk/mvsp/index.html). Thus, the genetic variability of sampled individuals was summarized into a few major components (e.g., PCO1, PCO2). We used the Doh assignment test (Paetkau et al. 1995, 1997) for species assignments based on the presence or absence of bands. Further, assignment scores were used to indicate the likelihood that an individual was assigned to a certain species (according to Doh assignment calculator). Differences in likelihood scores between Spotted Owls and Barred Owls reflected how much more likely it was that an individual was assigned as a Barred Owl than as a Spotted Owl, or vice versa.

\section{Results}

\section{Genetic Variation in Barred and Spotted Owls}

Barred Owls had significantly lower haplotype diversity in the Pacific Northwest than overall, suggesting a potential bottleneck in the new Northwest population. Haplotype diversity was also significantly higher in Spotted Owls overall and in the Pacific Northwest than in either Barred Owl comparison (Tables $3 \& 4$ ). Other diversity measures within species tended to be lower in Spotted Owls than in Barred Owls.

Maximum-likelihood trees were largely concordant and indicated that Barred and Spotted owls clearly differed in their mitochondrial control-region sequences (Fig. 2). The average pairwise sequence divergence between species was $13.9 \%$. All three methods segregated Barred and Spotted owls into two separate clades. The Spotted Owl clade was further resolved into two sister clades, representing a Northern Spotted Owl clade and a California/Mexican Spotted Owl clade. The Barred Owl clade was resolved into two clades, one containing only haplotypes from the northern portion of their range and the other containing a mixture of southern and northern haplotypes. The majority of Barred Owl haplotypes present in the Pacific Northwest were contained in the former clade, hence from the northern portion of the Barred Owl range. This provides support for the contention that the Barred Owl expansion occurred via a northern route.

Amplified fragment-length polymorphism analyses resulted in amplification of approximately 450 bands based on four primer combinations (Table 5). In the initial scoring, where 10 individuals of each species were included, 14 bands differed substantially in frequency between species and were diagnostic for each species. These diagnostic bands (Table 5) were then scored for all individuals. Doh assignment scores for each population reflected differences between assigned likelihoods for each species (assignment score for Barred Owl minus assignment score for Spotted Owl), as indicated in Fig. 3. All Barred Owls had positive values and all Spotted Owls had negative values, which means they were all correctly assigned to their respective species. Hybrid owls had intermediate scores, reflecting the fact that they have bands from both parental species. There was no overlap in frequency distributions between the two species. Thus, both statistical methods showed that, in concordance with mtDNA data, selected AFLP markers differed substantially between species and can be used for species identification.

Principal coordinate analyses of diagnostic bands further indicated significant differences in PCO1 between Spotted Owl subspecies (ANOVA $F_{2,34}=8.7, p<0.001$ ) but revealed no significant differences between Barred Owl subspecies. Intraspecific resolution may have been low, however, because the scored AFLP bands were selected based on their usefulness for species identification in hybrids.

\section{Hybrid Identification}

Among seven hybrids analyzed for parental identity, six hybrid haplotypes grouped with Barred Owl sequences, suggesting a Barred Owl mother (Tables 2 \& 3; Fig. 2). 


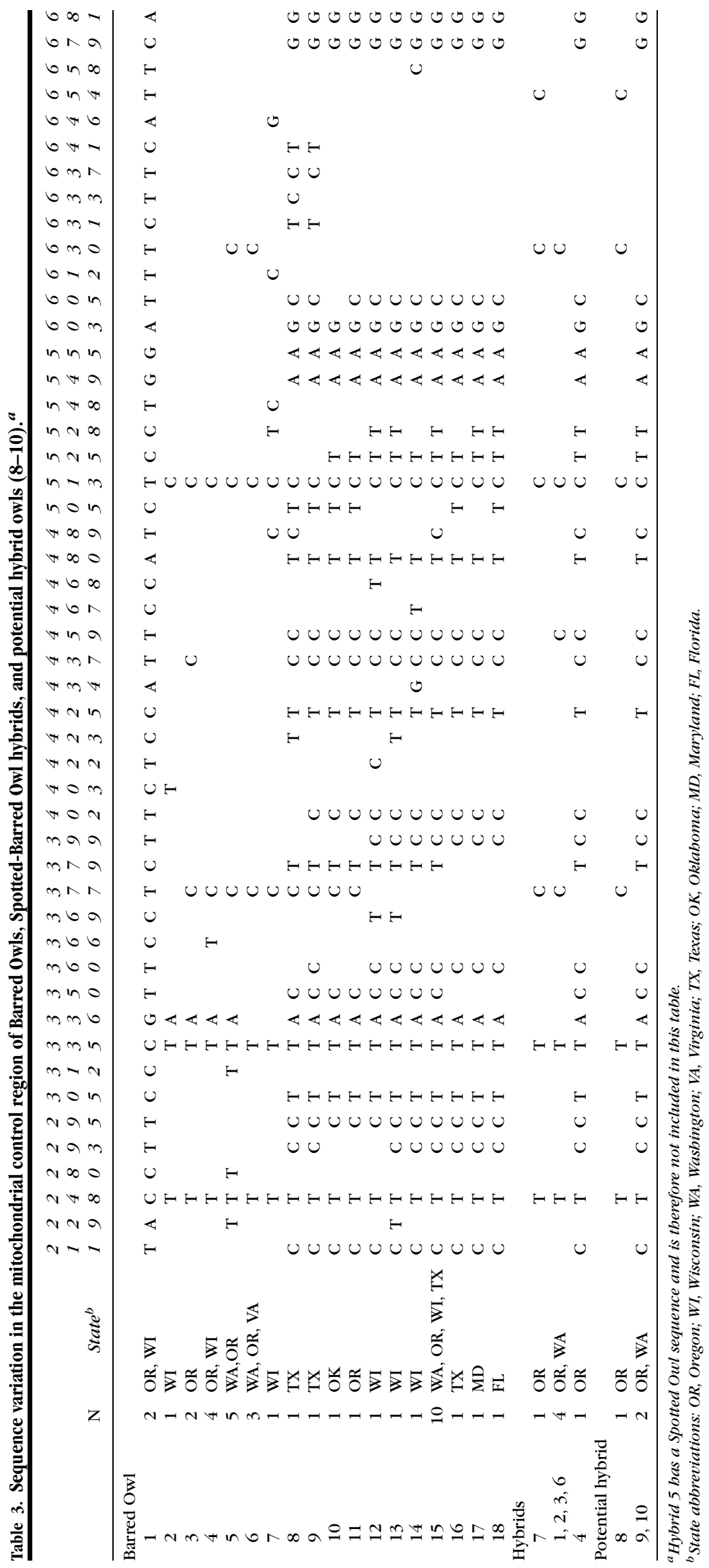




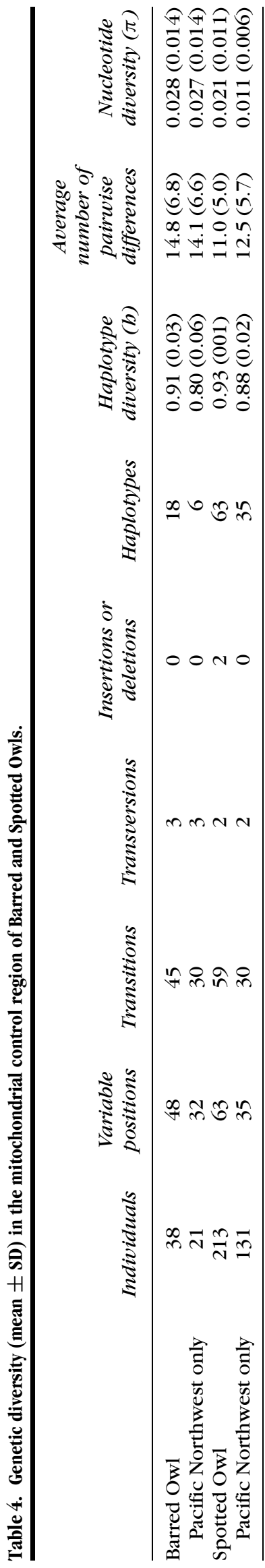

Hybrid sequences were present in both Barred Owl phylogenetic clades. Five individuals (hybrids 1, 2, 3, 6, and 7) differed by a single base pair from Barred Owl haplotype 6. One individual (hybrid 4) had a mtDNA sequence identical to that of Barred Owl haplotype 15 (Table 3). An additional bird (hybrid 5; Tables $2 \& 3$ ) had a mtDNA haplotype that clustered with the Spotted Owl clade (Fig. 2). Its mtDNA sequence was identical to haplotype NSO5, which is common among Northern Spotted Owls in Oregon (Haig et al. 2004).

Amplified fragment-length polymorphism analyses confirmed that all owls identified as hybrids in the field were indeed hybrids. Assignment tests indicated that hybrids were found between distributions of the two species on the frequency distribution of log-likelihood scores (Fig. 3).

Three potential hybrids, for which the taxonomic status had been questioned by field biologists (hybrids 810), had mtDNA haplotypes that clustered within the Barred Owl clade. Assignment tests of AFLP bands for these individuals indicated that they had log-likelihood differences typical of Barred Owls; hence, they were classified as Barred Owls and not hybrids (Fig. 3).

\section{Discussion}

\section{Species Identification}

Our results indicate that it is possible to identify Spotted and Barred owls and their hybrids via molecular genetic methods. The markers are critical for forensics and law enforcement in cases where the taxonomic status of particular owls is uncertain and species or hybrid identification affects their legal protection. Molecular genetic methods have also been applied successfully in forensics work on other threatened species when identification by other methods has been difficult (e.g., abalone, Muchmore et al. 1998; whales, Palumbi \& Cipriano 1998; and sharks, Shivji et al. 2002). The markers will be of further value in addressing and implementing recovery strategies such as monitoring the rate or mechanisms of introgression. The two molecular genetic methods we used-mtDNA sequencing and AFLPs-are complementary, and we recommend a combination of the two.

Mitochondrial DNA and AFLP analyses clearly showed that Spotted and Barred owls are distinct species, and there was no indication of previous gene flow across species boundaries: control-region sequences showed a large genetic divergence between species and no signs of previous introgression. Amplified fragment-length polymorphism analyses revealed several species-specific bands and showed no overlap between species in principal coordinate analyses or assignment tests. Thus, our results do not support the notion that the two owls form a superspecies, as was suggested by Mayr and Short (1970). 


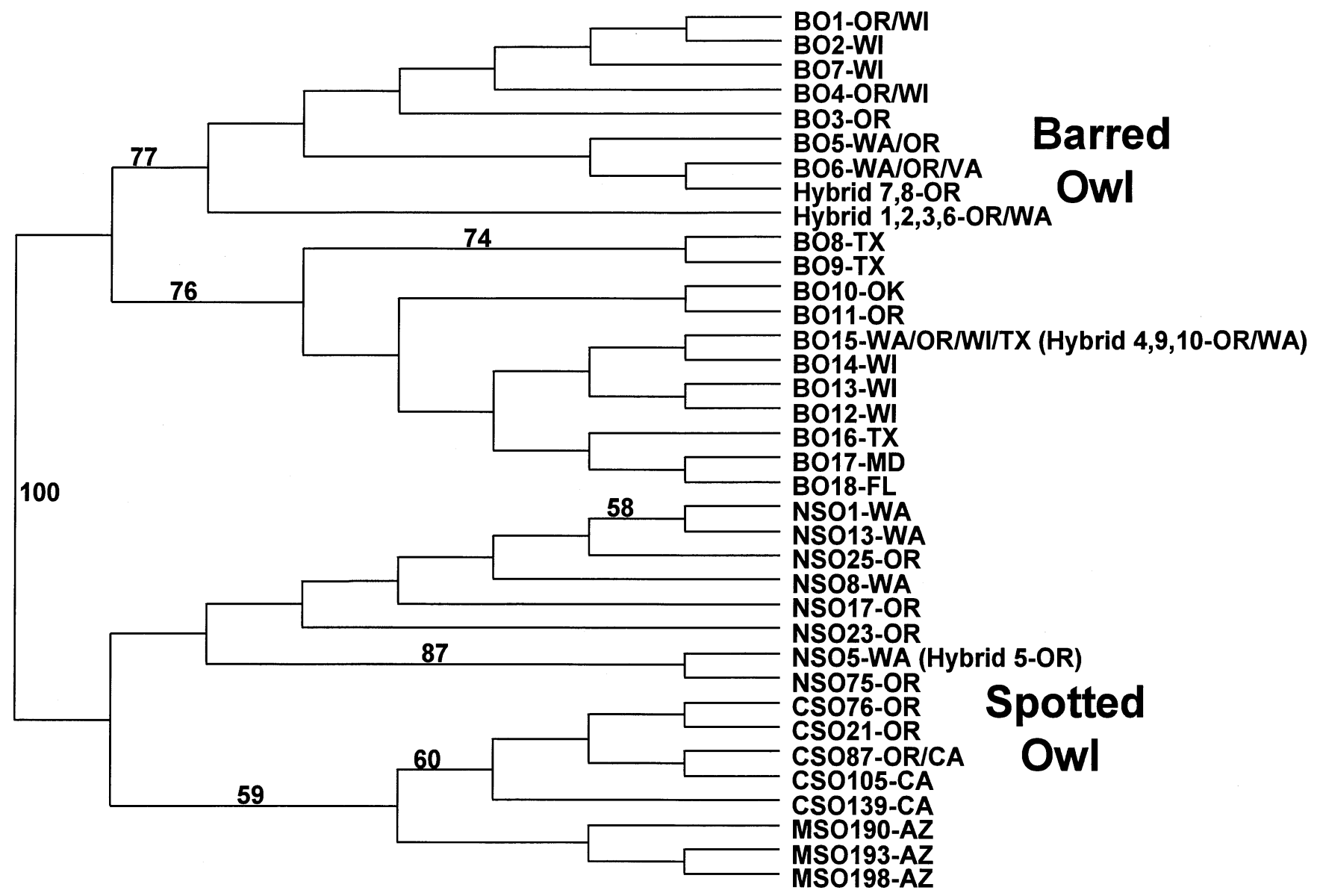

Figure 2. Maximum-likelibood tree of Barred Owl, Spotted Owl, and bybrid haplotypes based on 524 bp sequences from domain I and II of the mitochondrial control region. Bootstrap values of $\geq 50$ are reported (BO, Barred Owl; Spotted Owl subspecies: NSO, Northern Spotted Owl; CSO, California Spotted Owl. Location abbreviations: FL, Florida; CA, California; MD, Maryland; OK, Oklaboma; OR, Oregon; TX, Texas; VA, Virginia; WA, Washington; WI, Wisconsin. Spotted Owl haplotypes are from Haig et al. (2004).

Mitochondrial DNA and AFLP data also indicated significant differences between Spotted Owl subspecies, supporting subspecies identified previously (Barrowclough et al. 1999; Haig et al. 2004). Thus, if Barred Owls continue to extend into the ranges of California and Mexican Spotted Owls ( $S$. o. lucida), it will be possible to identify hybrid origins to species and subspecies. Having

Table 5. Primer combinations used for $\operatorname{AFLP}^{a}$ analyses and lengths of informative bands selected for Spotted-Barred Owl hybrid identification.

\begin{tabular}{lccl}
$\begin{array}{l}\text { Primer } \\
\text { combination }\end{array}$ & E-primer & M-primer & $\begin{array}{c}\text { Length of informative } \\
\text { bands }\end{array}$ \\
\hline $\mathrm{A}$ & $\mathrm{E}_{\mathrm{TAG}}{ }^{b}$ & $\mathrm{M}_{\mathrm{CGA}}$ & $204,228,464$ \\
$\mathrm{~B}$ & $\mathrm{E}_{\mathrm{TAG}}{ }^{b}$ & $\mathrm{M}_{\mathrm{CTG}}$ & - \\
$\mathrm{C}$ & $\mathrm{E}_{\mathrm{TCT}}{ }^{b}$ & $\mathrm{M}_{\mathrm{CGA}}$ & $109,149,178,183,214$ \\
$\mathrm{D}$ & $\mathrm{E}_{\mathrm{TCT}}{ }^{b}$ & $\mathrm{M}_{\mathrm{CTG}}$ & $140,160,175,181,245,292$ \\
\hline
\end{tabular}

${ }^{a}$ Amplified fragment-length polymorphism.

${ }^{b}$ Eco RI primers (E) were labeled with FAM at the $5^{\prime \prime}$ end. these subspecific markers developed will simplify law enforcement because it will be clear whether a violator has committed an ESA offense (Northern or Mexican Spotted Owl) or a MBTA offense (California Spotted Owl).

\section{Patterns of Hybridization}

The Barred Owl invasion and subsequent hybridization with Spotted Owls may affect Spotted Owl survival and fitness, which could result in outbreeding depression (Rhymer \& Simberloff 1996). In field studies and our analyses, hybrids resulting from crosses between male Spotted Owls and female Barred Owls are the most commonly reported, which may indicate a sex bias in gene flow from parental species (Kelly 2001; Kelly \& Forsman 2004). More data are needed to confirm this pattern, however, because males are easier to detect than females and Spotted Owls are more intensely studied than Barred Owls (Kelly 2001). Thus, pairs with Spotted Owl males may be detected and monitored more often. Also, in field studies, hybrids mated less frequently with Spotted Owls 


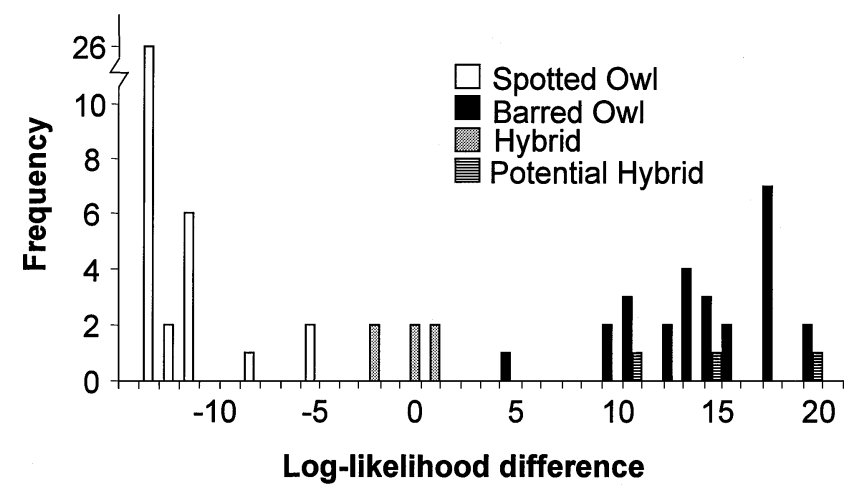

Figure 3. Frequency distribution of assigned likelibood differences (Barred Owl-Spotted Owl) for Barred Owls, Spotted Owls, bybrid owls, and potential bybrids, based on assignment test including 14 AFLP markers. The figure shows bow likely it is that each bird is assigned as either Spotted Owl or Barred Owl. The log-likelibood difference is the logaritbm of likelibood of being assigned as a Barred Owl minus the likelibood of being assigned as a Spotted Owl. Thus, Spotted Owls should be found at the negative values on the $x$-axis of this graph, Barred Owls at positive values, and bybrids at intermediate values between the two species.

than with Barred Owls. Three hybrids that changed mates between years all changed from spotted to Barred Owl mates (Table 2; Kelly 2001). The small data set on backcrosses (Table 2; Hamer et al. 1994; Kelly 2001) indicates that some hybrids are fertile and produce viable offspring by backcrossing. Once backcrossing has occurred, however, it is so difficult to identify resulting birds in the field-they resemble one of the parental species rather than a hybrid-that many are not known to biologists. Thus information on them is limited. Hybrids mated to Spotted Owls produced fewer offspring than those mated to Barred Owls (Table 2; Kelly 2001; Kelly \& Forsman 2004). These observations suggest that hybridization may have a negative influence on the fitness of Spotted Owls through genetic effects, but the mechanisms are unclear.

Several demographic factors also influence Spotted Owl populations through direct and indirect competition with Barred Owls. For example, Barred Owls are larger than Spotted Owls and may outcompete the smaller species and eventually exclude it from parts of its range, as indicated by the reduced occupancy of Spotted Owls in territories where Barred Owls have appeared (Kelly et al. 2003). Barred Owls also tend to have more offspring (Gutiérrez et al. 1995; Mazur \& James 2000), which further adds to the imbalance between the species. Finally, Dark et al. (1998) suggest that predation of Spotted Owls by Barred Owls occurs and may become a problem (E.D.F., personal observation).

\section{Legal Protection of Hybrids}

The legal status of hybrids is not clearly addressed in the ESA. In 1996 the USFWS drafted an intercross policy that would have provided protection for hybrids, but it was never finalized. Thus, lack of specific legal protection for hybrids under the ESA may constitute an indirect threat for Spotted Owls and other listed species with similar hybrid issues. Presently, without reliable molecular markers, individuals involved in killing (i.e., "take" defined in ESA section 2) a Spotted Owl may escape prosecution under the ESA by claiming that the bird in question was a hybrid when in fact it was a Spotted Owl.

There are, however, indirect means for hybrid protection under the ESA in an infrequently used provision in section 4(e) (invoked only seven times). Under this section, nonlisted species and hybrids between a listed and nonlisted species can be listed because of "similarity of appearance."

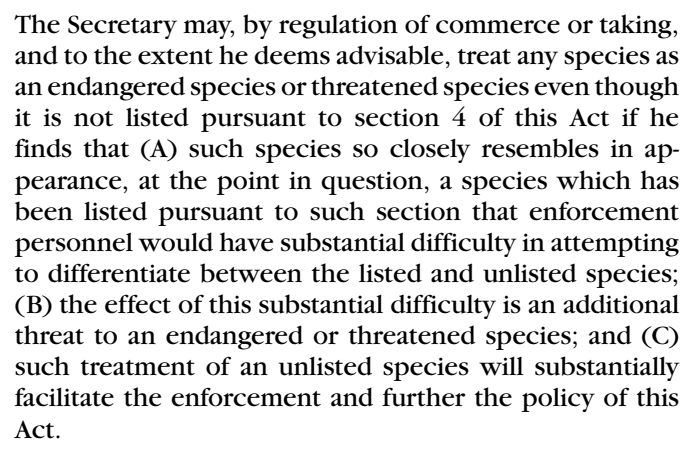

Although section 4(e) has never been invoked in a hybrid situation, it may be possible that hybrids and Barred Owls found in the range of the Northern Spotted Owl could be listed under section 4(e) if there was concern that a Spotted Owl would be taken by people claiming they thought it was a Barred Owl (S. Chambers, personal communication). This listing would provide hybrids and Spotted Owls with the maximum degree of protection from "take" (ESA section 2), although it would not provide habitat protection for them under ESA section 7. Sentences rendered in ESA violations can include jail time and fines into the thousands of dollars.

Section 4(e) has been previously invoked in cases where the listed species closely resembled a nonlisted species, making them more vulnerable to "take." For example, all Felis concolors were listed in Florida so that no one could kill a Florida panther and claim it was another species that had escaped from a roadside zoo (USFWS 1996). All desert tortoises (Gopherus agassizii) were listed in the Mojave desert to avoid people picking up individuals from the listed Mojave population and claiming they were from the nonlisted Arizona population (USFWS 1990). And American alligators (Alligator mississippiensis) are now listed in order to protect other crocodilians (USFWS 1987). Take is prohibited except by permit, 
so there is regulated trade. Additional examples include the bog turtle (Clemmys mublenbergii; USFWS 1997), American black bear (Ursus americanus; USFWS 1992), and Peregrine Falcon (Falco peregrinus; USFWS 1983).

It is not clear how a petition for direct listing of a hybrid under section 4 (e) would be considered by the USFWS. However, its acceptance of this notion might simplify the current situation in which the intercross policy has not been accepted or rejected and hybrids remain in limbo.

Alternatively, protection of hybrid owls could be limited to that provided by the Migratory Bird Treaty Act of 1918 (MBTA). This statute includes protection of all North American owl species and considers hybrids between listed species to be protected. If this strategy were implemented for Spotted Owl hybrids, the MBTA would provide penalties for those who killed hybrids, California Spotted Owls (S. o. occidentalis), or Barred Owls, and the ESA would continue to act as a deterrent to the taking of Northern Spotted Owls. Further, the USFWS would not have to undergo the extensive ESA listing process for Barred Owls or the hybrids. However, protection of hybrids under the MBTA does not carry the stiff penalties that result from violations of the ESA: maximum fines are $<\$ 500$.

In the case of Spotted Owls, there are no confusingly similar forms that completely lack protection: both Barred Owls and barred-spotted hybrids are protected under the MBTA. And in view of evidence that hybridization with Barred Owls poses a demographic threat to Spotted Owls, it seems contrary to the intent of the ESA to confer full ESA protection on hybrids in this case. Thus, invoking MBTA may be the most appropriate way to address the hybrid issue for Spotted Owls. However, this leaves unresolved the status of hybrids between most ESA-listed and nonlisted species, because the MBTA applies only to birds. Even then, it will not always solve problems facing an avian species.

Recognition of lesser-acknowledged aspects of the ESA and MBTA provides hope for appropriate conservation of listed species and their hybrids (Haig \& Allendorf 2005). Awareness of these opportunities (e.g., use of section $4[e])$ is important because a large fraction of all species have a hybrid origin or hybridize with closely related species (Jones et al. 1995; Soltis \& Gitzendanner 1999; Wolf et al. 2001). If the number of Spotted Owls continues to decline and the Barred Owl invasion advances farther into the range of the Spotted Owl as expected, hybridization between these species will almost certainly continue to occur. There are no plans to mitigate this problem because as yet no plausible solutions are known. Thus, in the future, listed species in similar predicaments may depend not only on direct conservation efforts but on full implementation of the legal authorities under ESA and MBTA. This case study illustrates why a renewed interest in how the ESA deals with hybrids is warranted.

\section{Acknowledgments}

We are most grateful to those who provided samples for this study: L. Diller (Simpson Timber); J. Ferguson (U.S. Fish and Wildlife Service Fish and Wildlife Forensic Laboratory); G. Fox, D. Garcia, S. Gremel (National Park Service); S. Sovern (Oregon State University); P. Loschl, M. Morris, T. Phillips, J. Reid (U.S. Forest Service Pacific Northwest Research Station), D. Rock (National Council for Air and Stream Improvement); M. Richardson; L. Schimmel (Cascades Raptor Center); C. Rodgers (Wildlife Images); J. Steel (Portland Zoo); and the U.S. Geological Survey Wildlife Health Laboratory (Madison, Wisconsin). We especially thank F. Allendorf, S. Chambers, A. Hecht, L. Kelly, and R. Waples for comments related to this paper. Thanks also go to M. Schwartz for providing preprints of manuscripts. Funding was provided by the National Fish and Wildlife Forensics Laboratory of the U.S. Fish and Wildlife Service, the Forest and Rangeland Ecosystem Science Center of the U.S. Geological Survey, and the U.S. Forest Service Pacific Northwest Research Station.

\section{Literature Cited}

Allendorf, F, R. F. Leary, P. Spruell, and J. K. Wenburg. 2001. The problems with hybrids: setting conservation guidelines. Trends in Ecology \& Evolution 16:613-622.

Barrowclough, G. F., R. J. Gutiérrez, and J. G. Groth. 1999. Phylogeography of Spotted Owl (Strix occidentalis) populations based on mitochondrial DNA sequences: gene flow, genetic structure, and a novel biogeographic pattern. Evolution 53: 919-931.

Bensch, S., A. J. Helbig, M. Salomon, and I. Seibold. 2002. Amplified fragment length polymorphism analysis identifies hybrids between two subspecies of warblers. Molecular Ecology 11:473-481.

Bert, T. M., D. M. Hesselman, W. S. Arnold, W. S. Moore, H. Cruz-Lopez, and D. Marrelli. 1993. High frequency of gonadal neoplasia in hard clam (Mercenaria) hybrid zone. Marine Biology 117:97-104.

Dark, S. J., R. J. Gutiérrez, and G. I. Gould. 1998. The Barred Owl (Strix varia) invasion in California. Auk 115:50-56.

Dunbar, D. L., B. P. Booth, E. D. Forsman, A. E. Hetherington, and D. J. Wilson. 1991. Status of the Spotted Owl, Strix occidentalis, and Barred Owl, Strix varia, in Southwestern British Columbia. Canadian Field-Naturalist 105:464-468.

Felsenstein, J. 1985. Confidence limits on phylogenies: an approach using the bootstrap. Evolution 39:783-791.

Forsman, E. D., S. DeStefano, M. G. Raphael, and R. J. Gutiérrez, editors 1996. Demography of the Northern Spotted Owl. Studies In Avian Biology 17:1-123.

Gill, F. B. 1997. Local cytonuclear extinction of the Golden-winged Warbler. Evolution 51:519-525

Gottelli, D., C. Sillero-Zubiri, G. D. Applebaum, M. S. Roy, D. J. Girman, J. Garcia-Moreno, E. A. Ostranders, and R. K. Wayne. 1994. Molecular genetics of the most endangered canid: the Ethiopian wolf Canis simensis. Molecular Ecology 3:301-312.

Grant, J. 1966. The Barred Owl in British Columbia. Murrelet 47:39-45.

Grant, P. R., and B. R. Grant. 1992. Hybridization of bird species. Science 256:193-197.

Gutiérrez, R. J., A. B. Franklin, and W. S. LaHaye. 1995. Spotted Owl. No. 179 in A. Poole, P. Stettenheim, and F. Gill, editors. The birds of North America. The Academy of Natural Sciences, Philadelphia, and The American Ornithologists' Union, Washington, D.C.

Haig, S. M., T. D. Mullins, and E. D. Forsman. 2004. Subspecific relationships and genetic structure in the Spotted Owl. Conservation Genetics 5:(in press). 
Haig, S. M., and F. W. Allendorf. 2005. Hybrid policies under the U.S. Endangered Species Act. In press in F. Davis, D. D. Goble, G. Heal, and J. M. Scott, eds. The Endangered Species Act at Thirty: Lessons and Prospects. Island Press, New York.

Hall, T. A. 1999. BioEdit: a user-friendly biological sequence alignment editor and analysis program for Windows 95/98/NT. Nucleic Acids Symposium Series 41:95-98.

Hamer, T. E., E. D. Forsman, A. D. Fuchs, and M. L. Walters. 1994. Hybridization between Barred and Spotted Owls. Auk 111:487-492.

Holt, D. H., R. Domenech, and A. Paulson. 2001. Status and distribution of the Barred Owl in Montana. Northwestern Naturalist 82:102-110.

Houston, C. S., and K. J. McGowan. 1999. The westward spread of the Barred Owl. Blue Jay 57:190-195.

Kelly, E. G. 2001. The range expansion of the Northern Barred Owl: an evaluation of the impact on Spotted Owls. M.S. thesis. Oregon State University, Corvallis,.

Kelly, E. G., and E. D. Forsman. 2004. Recent records of hybridization between Barred Owls and Spotted Owls. Auk 12:806-810.

Kelly, E G., E. D. Forsman, and R.G. Anthony. 2003. Are Barred Owls displacing Spotted Owls? Condor 105:45-53.

Jones, J. K., Jr., R. D. Bradley, and R. J. Baker. 1995. Hybrid pocket gophers and some thoughts on the relationship of natural hybrids to the rules of nomenclature and the Endangered Species Act. Journal of Mammalogy 76:43-49.

Liu, Z., A. Nicholas, P. Li, and R. Dunham. 2000. Inheritance and usefulness of AFLP markers in channel catfish (Ictalurus punctatus), blue catfish (I. furcatus), and their F1, F2, and backcross hybrids. Molecular and General Genetics 258:260-268.

Mayr, E., and L. L. Short. 1970. Species of taxa of North American birds. Publication of the Nuttall Ornithological Club 9.

Mazur, K. M., and P. C. James. 2000. Barred Owl. No. 508 in A. Poole, P. Stettenheim, and F. Gill, editors. The birds of North America. The Academy of Natural Sciences, Philadelphia, and The American Ornithologists' Union, Washington, D.C.

Mock, K. E., T. C. Theimer, O. E. Rhodes, D. L. Greenberg, and P. Keim. 2002. Genetic variation across the historical range of the wild turkey (Meleagris gallopavo). Molecular Ecology 11:643-657.

Muchmore, M. E., G. W. Moy, W. J. Swanson, and V. D. Vacquier. 1998. Direct sequencing of genomic DNA for characterization of a satellite DNA in five species of Eastern Pacific abalone. Molecular Marine Biology and Biotechnology 7:1-6.

O'Brien, S. J., and E. Mayr. 1991a. Bureaucratic mischief: recognizing endangered species and subspecies. Science 251:1187-1188.

O'Brien, S. J., and E. Mayr. 1991b. Species hybridization and protection of endangered animals. Science 253:251-252.

Paetkau, D., W. Calvert, I. Stirling, and C. Strobeck. 1995. Microsatellite analysis of population structure in Canadian polar bears. Molecular Ecology 4:347-354.

Paetkau, D., L. P. Waits, P. L. Clarkson, L., Craighead, and C. Strobeck. 1997. An empirical evaluation of genetic distance statistics using microsatellite data from bear (Ursidae) populations. Genetics 147:1943-1957.

Palumbi, S. R., and F. Cipriano. 1998. Species identification using genetic tools: the value of nuclear and mitochondrial gene sequences in whale conservation. Journal of Heredity 5:459-464.

Peterson, A. T., and C. R. Robins. 2003. Using ecological-niche modeling to predict Barred Owl invasions with implications for Spotted Owls. Conservation Biology 17:1161-1165.

Posada, D., and K. A. Crandall. 1998. Modeltest: testing the model of DNA substitution. Bioinformatics 14:817-818.

Reichard, T. A. 1974. Barred owl sightings in Washington. Western Birds 5:138-140.

Rhymer, J. M., and D. Simberloff. 1996. Extinction by hybridization and introgression. Annual Review of Ecological Systematics 27:83-109.

Rhymer, J. M., M. J. Williams, and M. J. Braun. 1994. Mitochondrial analysis of gene flow between New Zealand Mallards (Anas platyrbynchos) and Grey Ducks (A. superciliosa). Auk 111:970-978.

Rohwer, S., E. Bermingham, and C. Wood. 2001. Plumage and mito- chondrial DNA haplotype variation across a moving hybrid zone. Evolution 55:405-422.

Rozas, J., and R. Rozas. 1999. DnaSP version 3: an integrated program for molecular population genetics and molecular evolution analysis. Bioinformatics 15:174-175.

Saetre, G.-P., T. Borge, J. Lindell, T. Moum, C. Primmer, B. C. Sheldon, J. Haavie, A. Johnsen, and H. Ellegren. 2001. Speciation, introgressive hybridization and non-linear rate of molecular evolution in flycatchers. Molecular Ecology 10:737-749.

Sambrook, J., E. F. Fitsch, and T. Maniatis. 1989. Molecular cloning: a laboratory manual. 2nd edition. Cold Spring Harbor Laboratory Press, Cold Spring Harbor, New York.

Schneider, S., D. Roessli, and L. Excoffier. 2000. Arlequin version. 2.000: a software for population genetics data analysis. Genetics and Biometry Laboratory, University of Geneva, Geneva, Switzerland.

Schwartz, M. K., K. L. Pilgrim, K. S. McKelvey, E. L. Lindquist, J. J. Claar, S. Loch, and L. R. Ruggiero. 2004. Hybridization between Canada lynx and bobcats: genetic results and management implications. Conservation Genetics 5:349-355.

Shivji, M., S. Clarke, M. Pank, L. Natanson, N. Kohler, and M. Stanhope. 2002. Genetic identification of pelagic shark body parts for conservation and trade monitoring. Conservation Biology 16:1036-1047.

Smith, H. G., L. Wennerberg, and T. von Schantz. 1996. Adoption or infanticide: options of replacement males in the European Starling. Behavioural Ecology and Sociobiology 38:191-197.

Soltis, P. S., and M. A. Gitzendanner. 1999. Molecular systematics and the conservation of rare species. Conservation Biology 13:471-483.

Swofford, D. L. 2002. Phylogenetic analysis using parsimony (PAUP*). Version 4.0b9. Smithsonian Institution, Washington, D.C.

Tamura, K., and M. Nei. 1993. Estimation of the number of nucleotide substitutions in the control region of mitochondrial DNA in humans and chimpanzees. Molecular Biology and Evolution 10:512-526.

Taylor, A. L., and E. D. Forsman. 1976. Recent range extensions of the Barred Owl in western North America, including the first records for Oregon. Condor 78:560-561.

U.S. Fish and Wildlife Service. 1983. Final rule to reclassify Arctic Peregrine Falcon from endangered to threatened; clarify the status of American Peregrine Falcon (Falco americanus anatum) in some parts of its range; and classify all free-flying peregrine falcons in the conterminous 48 United States under similarity of appearance provisions under section 4(e) of the Act (48 FR8796). Federal Register 49:10520.

U.S. Fish and Wildlife Service. 1987. Reclassification of American alligator to threatened due to similarity of appearance throughout remainder of its range. Federal Register 52:21059-21064

U.S. Fish and Wildlife Service. 1990. Determination of threatened status for the Mojave population of the desert tortoise. Federal Register 55:12178-12191.

U.S. Fish and Wildlife Service. 1992. Threatened Status for the Louisiana black bear and related rules. Federal Register 57:588-595.

U.S. Fish and Wildlife Service. 1996. Proposed policy and proposed rule on the treatment of intercrosses and intercross progeny (the issue of "hybridization"). Federal Register 61:4709-4713.

U.S. Fish and Wildlife Service. 1997. Final rule to list the Northern population of the bog turtle as threatened and the southern population as threatened due to similarity of appearance. Federal Register 62:59605-59623.

Vos, P., R. Hogers, M. Bleeker, M. Reijans, T. van de Lee, M. Hornes, A. Frijters, J. Pot, J. Peleman, M. Kuiper, and M. Zebeau. 1995. AFLP: a new technique for DNA fingerprinting. Nucleic Acids Research 23:4407-4414.

Wolf, D. E., N. Takebayashi, and L. H. Rieseberg,. 2001. Predicting the risk of extinction through hybridization. Conservation Biology 15:1039-1053.

Wright, P.L. 1977. Further bird records from western Montana. Condor 78:418-420.

Wright, P. L., and G. D. Hayward. 1998. Barred Owl range expansion into the central Idaho wilderness. Journal of Raptor Research 32:77-81. 